\title{
Mutations in gld-1, a female germ cell- specific tumor suppressor gene in Caenorhabditis elegans, affect a conserved domain also found in Src-associated protein Sam68
}

\author{
Allan R. Jones and Tim Schedl ${ }^{1}$ \\ Department of Genetics, Washington University School of Medicine, St. Louis, Missouri 63110 USA
}

\begin{abstract}
The gld-1 gene of Caenorhabditis elegans is a germ-line-specific tumor suppressor gene that is essential for oogenesis. We have cloned the gld-1 gene and find that it encodes two proteins that differ by 3 amino acids. The predicted proteins contain a $\sim 170$-amino-acid region that we term the GSG domain (GRP33/Sam68/GLD-1), on the basis of significant similarity between GLD-1, GRP33 from shrimp, and the Src-associated protein Sam68 from mouse (also described as GAPap62 from humans). A conserved structural motif called the KH domain is found within the larger GSG domain, suggesting a biochemical function for GLD-1 protein in binding RNA. The importance of the GSG domain to the function of gld-1 in vivo is revealed by mutations that affect 5 different conserved GSG domain residues. These include missense mutations in an absolutely conserved residue of the $\mathrm{KH}$ domain that eliminate the tumor suppressor function of gld-1.
\end{abstract}

[Key Words: C. elegans; germ-line development; tumor suppressor; KH domain; GSG domain]

Received March 21, 1995; revised version accepted April 28, 1995.

An important contribution to our understanding of cancer biology has been the identification of tumor suppressor genes in which loss of gene function is a factor in tumor formation. A number of tumor suppressor genes are involved in the cell cycle (for recent review, see Hartwell and Kastan 1994). These include cell cycle checkpoint genes (e.g., p53) and DNA repair genes (e.g., MSH2). Other tumor suppressor genes, possibly including WT1 (Kreidberg et al. 1993), appear to be tied to development, acting in cell type specification or developmental aspects of cell cycle control.

Two recent reports describe genetic studies of $g l d-1$, a tumor suppressor gene that is required for normal oocyte development in the nematode Caenorhabditis elegans (Francis et al. 1995a,b). In wild-type C. elegans, diploid animals with a single $\mathrm{X}$ chromosome develop as males that make only sperm, whereas diploids with two $\mathrm{X}$ chromosomes are hermaphrodites that produce some sperm before switching to the production of oocytes (Fig. 1). gld-1 has no essential function in the male germ line or soma but is absolutely required for oogenesis in $\mathrm{XX}$ hermaphrodites (Francis et al. 1995a). In gld-1(null) hermaphrodites, germ cells that should develop as oocytes

${ }^{1}$ Corresponding author. enter the meiotic pathway normally and progress as far as the pachytene stage of meiotic prophase. However, these cells then exit meiotic prophase, re-enter a mitotic cell cycle, and proliferate ectopically to produce a germline tumor. Neither the somatic sexual environment nor the chromosomal sex appear important for generation of the hermaphrodite tumor. Instead, tumor formation requires only that the germ-line sex determination pathway be set in the female mode that normally leads to oogenesis (Francis et al. 1995b). On the basis of these properties, gld-1 can be regarded as a tumor suppressor locus that acts to direct oocyte differentiation and meiotic prophase progression (Fig. 1, function 1).

Previous studies have indicated that in addition to its essential role in oogenesis, gld-1 is likely to participate in at least two other aspects of germ-line development. gld-1 appears to act to regulate mitotic proliferation negatively among premeiotic germ-line stem cells (Fig. 1, function 2), as a gld-1(null) allele can partially suppress the premeiotic proliferation defects conferred by certain alleles of the glp-1 gene (Francis et al. 1995b). In contrast to its role in oogenesis, the activity of gld-1 in premeiotic germ cells is nonessential, possibly because of genetic redundancy, and functions in both the male and hermaphrodite germ lines. The finding that gld-1 acts to regulate premeiotic proliferation negatively suggests 
Figure 1. gld-1 $|+|$ functions in three aspects of C. elegans germ-line development. Diagrammed is one gonad arm from a wild-type adult hermaphrodite. Germ cell nuclei with characteristic chromosomal morphology are shown. Male germ-line development is complete by the adult stage shown; mature sperm are located proximally within the gonad. Germ-line stem cell proliferation (distal mitotic); entry (transition zone) and progression through meiotic prophase (pachytene through diakinesis); and oocyte development are ongoing throughout adulthood (for review, see Clifford et al. 1994). The three gld-1 $(+)$ functions (see text) include (1) an essential function in directing oocyte development and progression through pachytene for germ cells that are developing in the female mode; (2) a nonessential and sex nonspecific function in negatively regulating proliferation in premeiotic germ cells; and (3) a nonessential function in male sex determination in the hermaphrodite germ line. The diagram is not meant to imply spatial or temporal modes of gld-1 function.

that the role of gld-1 in directing oocyte development may also involve negative regulation of mitotic cell cycle factors.

The third function of gld-1 is promotion of the male germ cell fate in the hermaphrodite germ line (Fig. 1, function 3). Because a reduced level of spermatogenesis is observed in XX hermaphrodites with only one functional gld-1 allele, the role of the gene in promoting spermatogenesis appears to be haploinsufficient. gld-1 is not required for sperm formation in either sex, however, and its role in promoting hermaphrodite spermatogenesis may be limited to assisting the set of genes ( $f \circ g-1, f \circ g-3$, and the fem genes) that act to specify the male fate (Francis et al. 1995b). Several classes of gld-1 gain-of-function (gf) alleles have been characterized that cause transformations in germ-line sexual fate by poisoning the germline sex determination process. Two classes of $g f$ alleles feminize the XX (hermaphrodite) germ line dominantly (causing all germ cells to develop as oocytes); a third class of $g f$ mutations feminizes both the $\mathrm{XX}$ and $\mathrm{XO}$ (male) germ lines; and a fourth class masculinizes the XX germ line (causing germ cells to develop inappropriately as sperm instead of oocytes). Thus, gld-1 can be mutated in different ways to cause $g f$ disruptions in the process that specifies germ-line sexual fates.

The genetic properties of $g l d-1$, including its multiple germ-line functions and classes of mutant alleles, suggest that the gene's regulation and function are likely to be complex. This report presents a molecular study of gld-1 that includes sequence analysis of the wild-type gene and 32 mutants.

\section{Results}

\section{Physical mapping of the gld-1 locus}

gld-1 maps genetically to chromosome I between unc-13 and lin-10 (Fig. 2A; Francis et al. 1995a). This region is represented entirely by an ordered set of yeast artificial chromosome (YAC) and cosmid clones (Coulson et al. 1988). Through PCR deletion mapping (Barstead et al. 1991; see Materials and methods), we delimited the physical location of gld-1 to a five-cosmid interval (flanked by F29D11 and ZK1014; Fig. 2B).

Genomic Southern blot analyses revealed that two gld-1 alleles are correlated with restriction fragment length polymorphisms (RFLPs). We found an insertion of $2.3 \mathrm{~kb}$ associated with gld-1(q343), and a small deletion associated with the psoralen-induced allele, gld-1 (q485). Both RFLPs are detected by a $6.8-\mathrm{kb}$ subclone (pAJ37) of cosmid C29D7 (Fig. 2C).

\section{Gene structure}

We sequenced most of pAJ37 (data not shown). The portion of this genomic sequence corresponding to gld-1 cDNAs (see below) is shown in Figure 3. All 32 gld-1 mutations (Fig. 6, below) affect the gene as defined in Figure 3, providing strong evidence that this is the gld-1 gene.

To determine the intron/exon structure of gld-1, we isolated cDNA clones from a mixed-stage cDNA library (see Materials and methods). One clone, judged to be nearly full length (pLAJ1), was sequenced in its entirety (Fig. 3). The intron/exon structure of gld-1 is summarized in Figure 2D. The cDNA contains a single open reading frame of 1392 nucleotides. A 5'-untranslated region (UTR) of $16 \mathrm{nts}$ is trans-spliced to SLl (see below). The 3' UTR is $812 \mathrm{nts}$ and ends with a stretch of poly|A) 10 nts downstream of the consensus polyadenylation signal AATAAA. To determine the precise $5^{\prime}$ end of the gld-1 transcript, we isolated additional cDNA clones by $5^{\prime}$ rapid amplification of CDNA ends (RACE)-PCR (Frohman et al. 1988). Sequence of these clones (see Materials and methods/ verified that the gld-1 transcript is trans-spliced to SLl (Krause and Hirsh 1987).

Northern blot analysis detected a single band of $\sim 2.5$ $\mathrm{kb}$ in both mixed-stage poly(A)-selected RNA and total RNA from various developmental stages and germ-line mutants (described below; A. Jones and T. Schedl, unpubl.). This transcript size is consistent with that of the cDNA pLAJ1 $(2.3 \mathrm{~kb})$. However, when sequencing 5' RACE-PCR products, we discovered evidence for an al- 


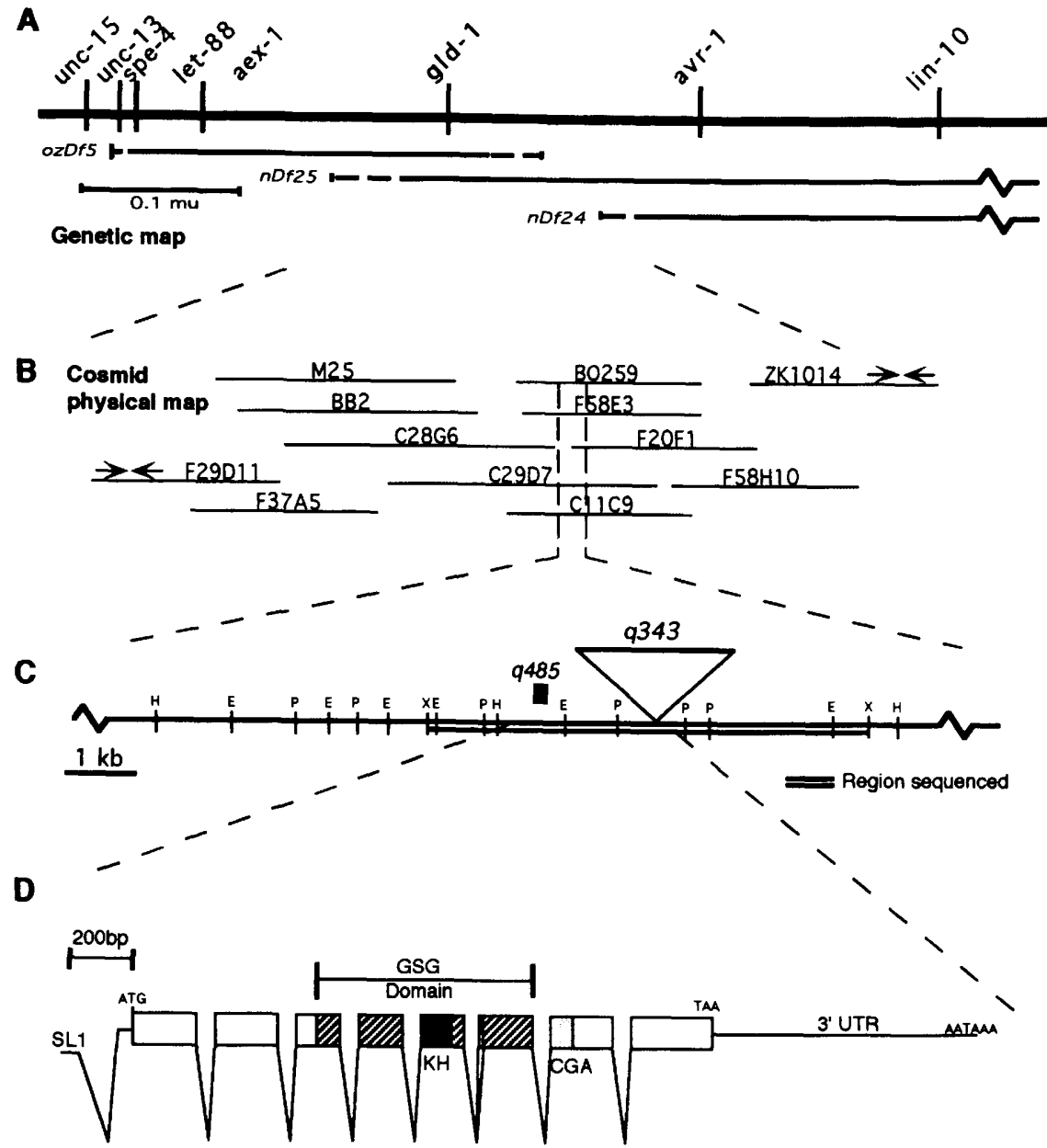

Figure 2. A summary of the mapping of the gld-1 locus. (A) A genetic map showing the position of gld-1 in relation to other genetic markers on chromosome I (adapted from Francis et al. 1995a). Deficiencies (ozDf5, $n D f 24$, and $n D f 25)$ are shown with approximate end points. $(B) \mathrm{A}$ contiguous physical map showing the cosmids from the physical mapping project (Coulson et al. 1988) that fall within the two PCR assays (opposing arrows) used to delimit the region containing gld-1 (see Materials and methods). (C) A restriction map showing the position of restriction sites as well as the two RFLPs associated with gld-1 alleles, as determined from Southern blotting and subcloning. (X)XhoI; (H)HindIII; (E)EcoRI; (P)PstI. q485 (D) is a small deletion; $q 343$ is a $2.3-\mathrm{kb}$ insertion. The double bar indicates the subclone from cosmid C29D7 (pAJ37) that was sequenced. ( $D$ ) A composite summary of the gene structure as determined from cDNA sequencing. Coding regions are shown as rectangles. The gene structure represents the two transcripts as described in the text, with the alternate splice on exon 6 occurring as shown. Trans-splicing occurs at the $5^{\prime}$ end of the transcript to the 22-nucleotide leader SLl (see text). Putative initiator methionine codon (ATG), stop codon (TAA), polyadenylation signal (AATAAA), and 3'-untranslated region (3' UTR) occur as shown. Regions of homology as described in the text are shown as shaded regions superimposed on the gene structure. The GSG domain (see text) is hatched and includes the single $\mathrm{KH}$ motif in exon 5 (ם). The CGA region (light shading; see Fig. 4) is in exon 7 as shown. ternatively spliced transcript. One cDNA clone contained 9 additional nucleotides at the $5^{\prime}$ end of exon 6 . This alternative splice inserts 3 amino acids into the predicted protein (Fig. 3). We hypothesized that two transcripts are produced from the gld-1 locus that are colinear except for 9 nucleotides. Consistent with this hypothesis, reverse transcriptase-PCR (RT-PCR) experiments using primer sets made to amplify specifically only the alternative splice product give single-band products of the predicted sizes (data not shown).

\section{Conserved domains in the GLD-1 predicted protein}

Conceptual translation of the cDNA pLAJ1 yields a 463 amino-acid protein. BLAST data base searches (Altschul et al. 1990) revealed significant sequence identity with several proteins. These proteins are shown in alignment in Figure 4A, and diagrammatically in Figure 4B. The most extensive similarity is found with GTPase-activating protein (GAP)-associated p62 (GAPap62) from humans (Wong et al. 1992), and glycine-rich protein
(GRP33) from brine shrimp (Cruz-Alvarez and Pellicer 1987). The sequence reported for GAPap62 is highly related to a $68-\mathrm{kD}$ protein from mouse that is associated with Src during mitosis, and we refer to this protein as Sam68 (for Src-associated in mitosis $68 \mathrm{kD}$; see Courtneidge and Fumagalli 1994/. The similarity between Sam68/GAPap62 and GRP33 has been reported previously (Wong et al. 1992). However, this original alignment is extended by $>50$ amino acids in the amino-terminal direction when GLD-1, Sam68, and GRP33 are aligned (Fig. 4A). We term the $\sim 170$-amino-acid region of similarity shared by these three proteins a GSG domain (for GRP33, Sam68, and GLD-1). Overall, the GSG domains of GLD-1 and Sam 68 are $34 \%$ identical and $61 \%$ similar.

Within the GSG domain is a smaller motif proposed to be involved in RNA binding, termed the $\mathrm{KH}$ domain ( $\mathrm{Si}$ omi et al. 1993a). Both GRP33 and Sam68 have been identified as containing a KH motif (Gibson et al. 1993; Siomi et al. 1993b). Other genes containing this motif include $F M R-1$, the gene responsible for fragile $\mathrm{X}$ syn- 
Figure 3. Genomic sequence of the gld-1 locus. The genomic nucleotide sequence encompassing the gld-1-coding region is shown with the putative coding region translated below. Splice sites (inverted L's) inferred from cDNA sequencing are shown. The alternate splice site-coding region for exon 6 is underlined with dashes, and the putative polyadenylation signal is underlined. This sequence has been given the GenBank accession no. U20535.

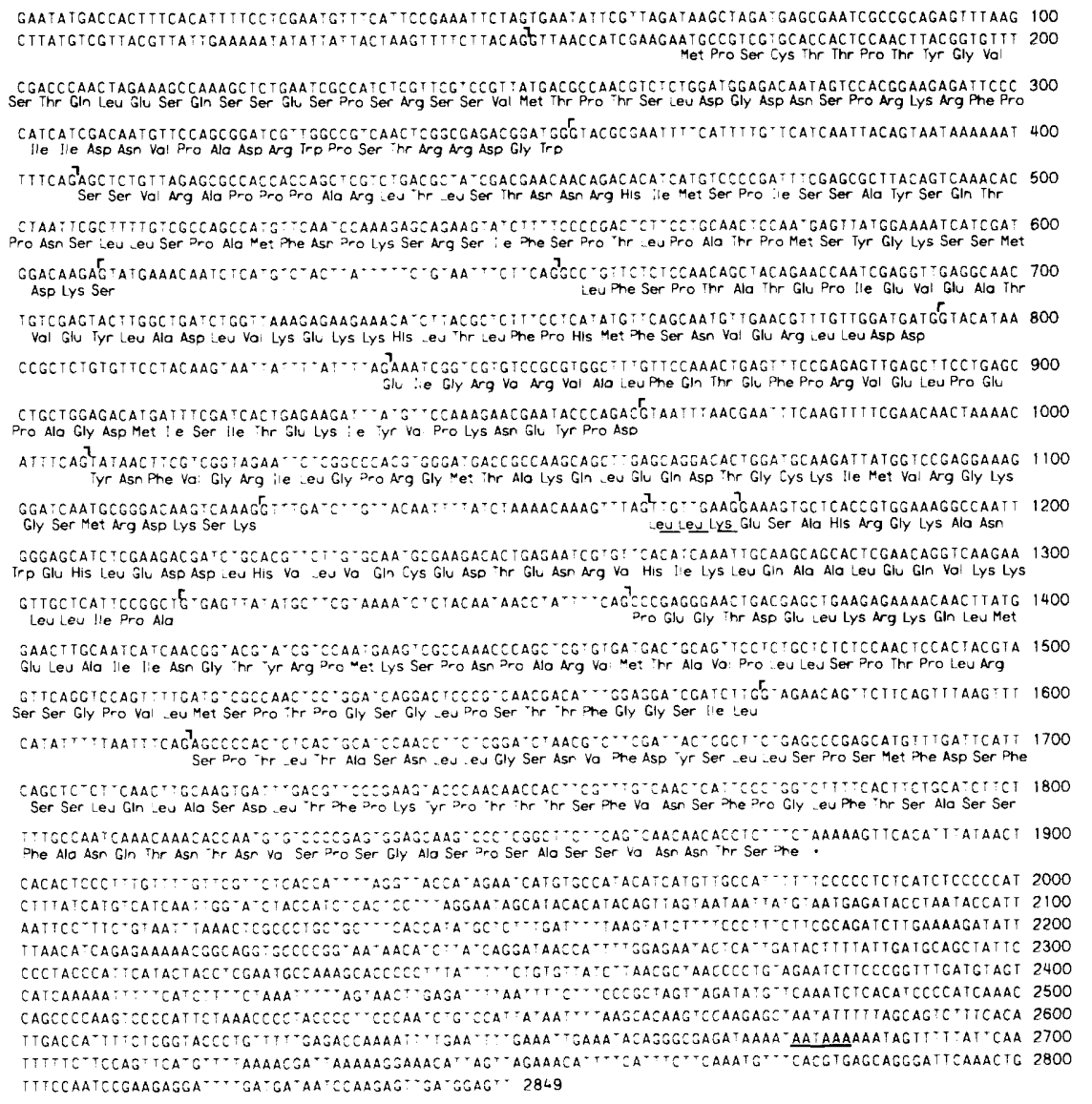

include part of the coding region of the gld-1 gene from the male/female nematode species Caenorhabditis remanei (data not shown; see Materials and methods). The gld-1 transcripts from both C. elegans and C. remanei contain identical trans-spliced SLl leaders, and the same length (although not identical) 5' UTRs. The partial coding region (corresponding to amino acids $1-370$ in $C$. elegans) showed $88 \%$ identity, with $99 \%$ similarity within the GSG domain and CGA region. All of the amino acids mutated in the gld-1 missense alleles described below are conserved in C. remanei.

\section{Molecular analysis of gld-1 mutations that affect oogenesis}

The gld-1 gene performs an essential function in directing oogenesis and a nonessential role in promoting spermatogenesis in the hermaphrodite (Francis et al. 1995a). Thirty-two gld-1 mutations have been placed into six classes (A-F) on the basis of the nature of germ-line phenotypes observed in homozygotes (Francis et al. 1995a). We determined the molecular lesions in each gld-1 allele (Table 1; Fig. 6; see Materials and methods).

Class A gld-1 alleles are null or strong loss-of-function mutations, which abolish the major function of gld-1. In $\mathrm{XX}$ animals homozygous for class $\mathrm{A}$ alleles, presumptive female germ cells never undergo oogenesis but, instead, form a tumor. As expected, many of the class A alleles 


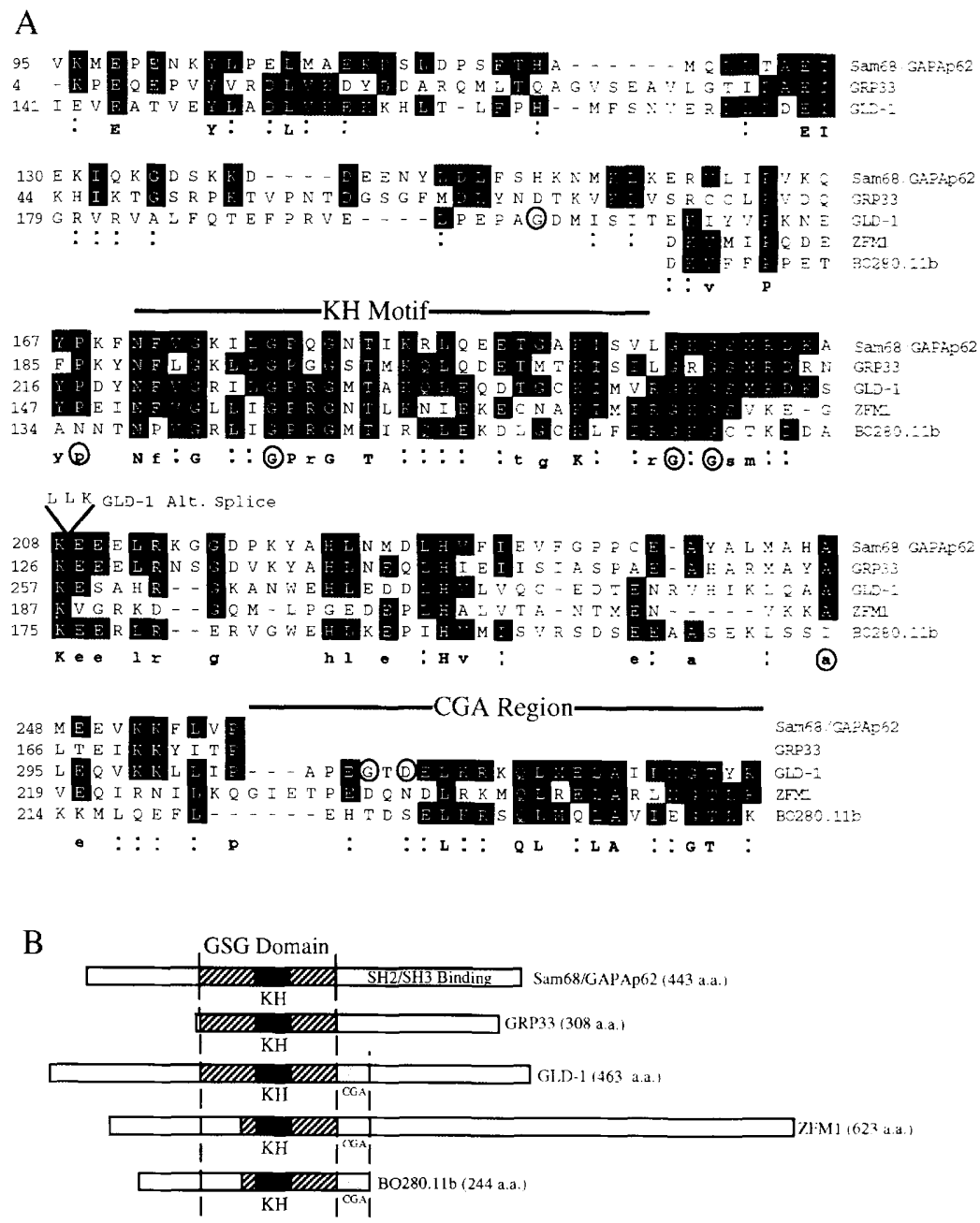

Figure 4. An alignment of five proteins. $(A) \mathrm{A}$ hybrid alignment of GLD-1 in either three-, four-, or five-way comparisons performed by the CLUSTAL $\mathrm{V}$ alignment program (Higgins et al. 1992). Aligned with GLD-1 are five proteins, GAP-associated p62 from humans (Sam68/GAPap62; see text), glycine-rich protein from $A r$ temia salina (GRP33; see text), ZFMl from humans (Toda et al. 1994), and BO280.11b from $C$. elegans (see text). Amino acid numbering is given at left, and nonaligned portions are not shown for clarity; the five-way alignment begins at residue 138 for ZFM1 and 125 for BO280.11b. For GLD-1, amino acid numbering refers to the product predicted by the cDNA pLAJl. The position of the alternative splice addition of 3 amino acids (see text) is shown inserted between amino acids 257 and 258 of the GLD-1 protein. For all alignments, amino acids that are present in a majority are shaded. Residues that are conserved in all proteins are listed below each line in uppercase letters, with conservative replacement [based on a score $\geqslant 0$ on a BLOSUM 62 matrix (Henikoff and Henikoff 1993)] indicated by a colon (:). In the five-way alignment, lowercase letters are used for residues found in three or four of the aligned proteins. Amino acids that are missense for gld-1 mutations (Table 1 ) are circled. The $\mathrm{KH}$ motif and the CGA region as defined in the text are delimited as shown. BLAST searches reveal that several cDNAs identified as expressed sequence tags (ESTs) in corn, Arabidopsis, mouse, and human are also predicted to contain portions of the GSG domain and CGA region (not shown). (B) Diagram illustrating the positions of the various regions of similarity aligned in $A$ within each of the five proteins. The GSG domain is delimited as shown (hatched region). Also shown is the position of the single $\mathrm{KH}$ motif (solid region) that lies within this larger region of homology (see text) and the CGA region (shaded region). The portion of the Sam68 protein responsible for binding to SH2 and SH3 domains (Weng et al. 1994, Richard et al. 1995) is shown to emphasize that it occurs outside of the region of homology with GLD-1.

contain lesions that are likely to eliminate gene function. $q 485$, the canonical genetic null mutation (Francis et al. 1995a), contains an 83-bp deletion that shifts the reading frame near the amino terminus of the predicted protein. In addition to another small deletion (oz127), other class A alleles contain premature stop codons $(q 365, q 268, q 495$, and $q 930 z 49)$, a splice site mutation ( $q 930 z 53)$, and missense mutations \{oz89, q93oz55, $q 361$, and oz17oz47). Of particular interest is that three of the class A missense mutations (0z89, q93oz55, and q361) affect a single residue (Gly-227 Ser or Asp) in the gld-1 $\mathrm{KH}$ motif. This glycine is absolutely conserved in the alignment of $\mathrm{KH}$ motifs (see Fig. 5).

The class $\mathrm{B}, \mathrm{E}$, and $\mathrm{F}$ gld -1 alleles are partial reductionof-function mutations that block oogenesis in either early or late stages. Class $B$ alleles show a recessive phenotype in which presumptive female germ cells arrest in pachytene of meiosis I. Most class B alleles are intragenic revertants of the class $\mathrm{C}$ allele $q 93$ (see below) and contain both the $q 93$ mutation and an additional change that is either missense ( $q 930 z 56, q 930 z 12$, and $q 930 z 45)$ or affects a splice site ( $q 930 z 52)$. oz116 is the only class $\mathrm{B}$ allele that was not obtained as an intragenic revertant. This mutation changes the 3' splice acceptor site in the last intron, from cagAGC to caaAGC. RT-PCR analysis revealed that the adjacent $A G$ is used as a splice acceptor at an appreciable level in oz116 RNA (see Materials and methods), resulting in a reading frameshift predicted to produce a carboxy-truncated protein.

One class B allele $(q 930 z 50)$ has a nonsense change in codon 13 of the predicted protein. Although this might be expected to be a molecular null mutation, $q 930 z 50$ does retain residual gene activity (Francis et al. 1995a). Two hypotheses to explain the residual $q 930 z 50$ gene activity are exon skipping during splicing (Fisher et al. 1993) and translational intiation at a downstream AUG.

The phenotypic classes $E$ and $F$ are each represented by a single allele. Both alleles produce abnormal oocytes and behave as partial loss-of-function mutations with respect to oogenesis (Francis et al. 1995a). The class E 


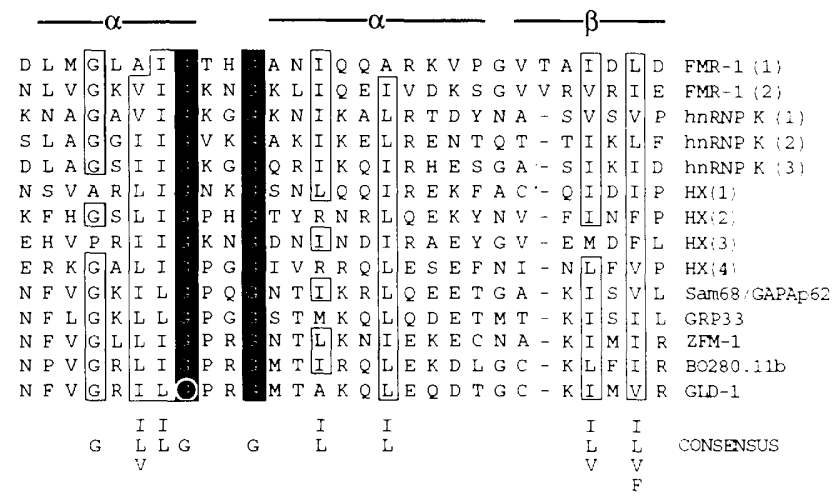

Figure 5. An amino acid alignment of the $\mathrm{KH}$ domain. The amino acid sequences of several $\mathrm{KH}$ domains are shown. The alignment is based on several descriptions of the content of the $\mathrm{KH}$ domain that have placed $>10$ different proteins ranging from bacteria to higher eukaryotes into the $\mathrm{KH}$ domain family (cf. Gibson et al. 1993). The $\alpha-\alpha-\beta$ structural predictions are delimited by lines above the alignment and are from Gibson et al. (1993). Shown in alignment are the KH domains from the human proteins hnRNP K $[\{1,2$, and 3\}; Siomi et al. 1993a], and FMR-1 [(1 and 2); Verkerk et al. 1991], a yeast protein HX $\mid(1,2$, 3, and 4); Delahodde et al. 1986), GRP33 (Cruz-Alvarez and Pellicer 1987), Sam68/GAPap62 (Wong et al. 1992), ZFM1 (Toda et al. 1994), BO280.11b (see Materials and methods), and GLD-1 (Fig. 3). Conserved hydrophobic residues are boxed, with the absolutely conserved glycine residues in black. The glycine residue circled in the GLD-1 protein is missense in three gld-1 tumorous mutations (see text). allele (q266), which is a $27-\mathrm{bp}$ deletion that removes 9 amino acids [including the last 6 amino acids of the CGA region (Fig. 6)], has an additional defect in hermaphrodite spermatogenesis (see below). This mutation creates a methionine codon over the deletion fusion.

The class $\mathrm{F}$ allele molecular lesion is a $2.3-\mathrm{kb}$ insertion in the middle of the gld-1 3' UTR. Sequence from the ends of the insertion (data not shown) was nearly identical to that of the transposable element, Tc2 (Ruvolo et al. 1992), thus providing the first report of a Tc2 insertion into a gene. RNA from a balanced $q 343$ strain [unc13(e51) gld-1(q343) / unc-15(e1214)] did not show aberrant-sized gld-1 transcripts on Northern blots /data not shown), suggesting that the element may be spliced out of gld-1 mRNA (e.g., Benian et al. 1993) or that it affects the stability of gld-1 mRNA.

\section{Molecular analysis of gld-1 mutations that affect hermaphrodite spermatogenesis}

Aside from its essential role in directing oogenesis, gld-1 has a nonessential role in germ-line sex determination, promoting spermatogenesis in hermaphrodites. Class D gld-1 alleles form normal oocytes. However, these two alleles eliminate hermaphrodite spermatogenesis [a feminization of the germ-line (Fog) phenotype] as the result of a $g f$ defect. In addition, class $\mathrm{D}$ alleles show a novel gld-1 defect; they feminize the XO male germ line, caus-

Class A

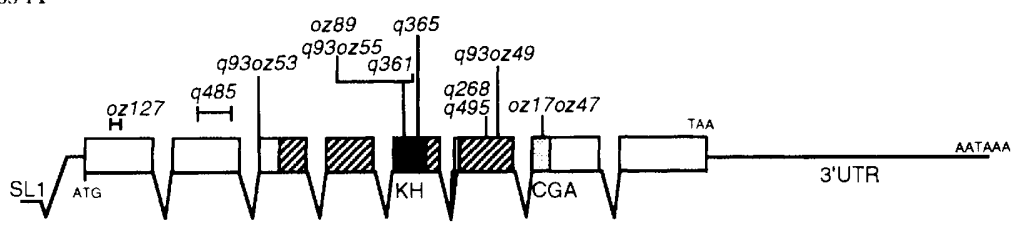

Class B
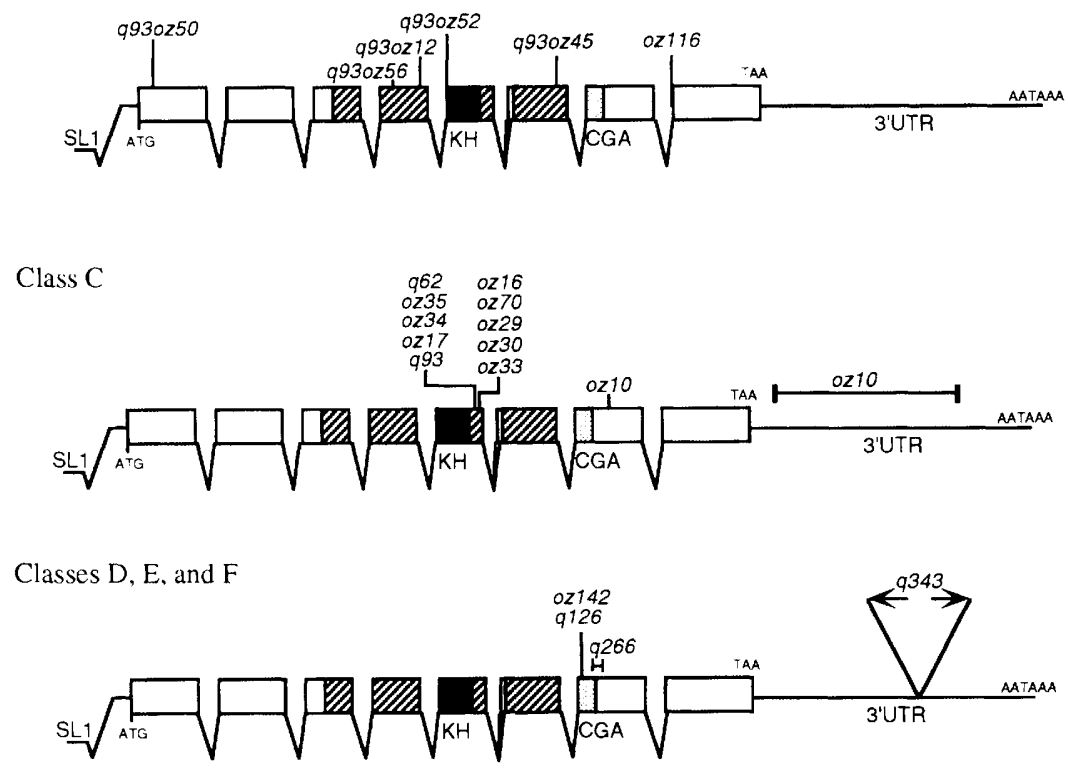

Figure 6. Molecular lesions in 32 alleles of gld1. A summary of the position of each mutation in relation to the structure of the gene (see legend to Fig. 2D) by phenotypic class (see Table 1 and text). Blocked lines (for oz127, q485, q266, and oz10) indicate deletions, opposite pointing arrows indicate an insertion /for q343; insertion not drawn to scale). For the intragenic revertants (e.g., $q 930 z 50)$, only the new mutation is shown 
Table 1. Molecular lesions of gld-1 alleles

\begin{tabular}{|c|c|c|c|}
\hline Allele & $\begin{array}{l}\text { Phenotypic } \\
\text { class }\end{array}$ & $\begin{array}{l}\text { Nucleotide } \\
\text { change }\end{array}$ & Predicted result of molecular lesion \\
\hline$q 485$ & $\mathrm{Al}$ (tum) & deletion of $481-563$ & shift in reading frame, multiple stop codons \\
\hline oz127 & A2 (tum) & deletion of $261-270$ & shift in reading frame, multiple stop codons \\
\hline$q 930 z 53$ & A2 (tum) & g 654 a & $3^{\prime}$ splice acceptor changed, exon 3 \\
\hline oz89, q93oz55 & A2 (tum) & g 1032 a & Gly-227 Ser \\
\hline$q 361$ & A2 (tum) & g 1033 a & Gly-227 Asp \\
\hline$q 365$ & A2 (tum) & c $1065 \mathrm{t}$ & Gln-238 Stop (uag) \\
\hline$q 268, q 495$ & A2 (tum) & g 1202 a & Trp-267 Stop (uga) \\
\hline$q 930 z 49$ & $\mathrm{~A} 2$ (tum) & c $1275 \mathrm{t}$ & Gln-292 Stop (uaa) \\
\hline $0 z 170 z 47$ & A2 (tum) & g 1374 a & Asp-310 Asn \\
\hline q93oz50 & B (undiff.) & c $206 \mathrm{t}$ & Gln-14 Stop \{uaa) \\
\hline q93oz56 & $B$ (undiff.) & g $907 \mathrm{a}$ & Gly-200 Glu \\
\hline$q 930 z 12$ & $\mathrm{~B}$ (undiff.) & c $958 \mathrm{t}$ & Pro-217 Leu \\
\hline q93oz52 & B (undiff.) & g 1007 a & $3^{\prime}$ splice acceptor changed, exon 5 \\
\hline$q 930 z 45$ & B (undiff.) & $\mathrm{g} 1281 \mathrm{a}$ & Ala-294 Thr \\
\hline$o z 116$ & B (undiff.) & g 1617 a & $3^{\prime}$ splice acceptor changed, exon 8 \\
\hline$q 93, o z 17, o z 34, o z 35, q 62$ & $\mathrm{Cl}(\mathrm{Mog})$ & g 1095 a & Gly-248 Arg \\
\hline$o z 30, o z 16, o z 29, o z 33, o z 70$ & $\mathrm{C} 2(\mathrm{Mog})$ & g 1101 a & Gly-250 Arg \\
\hline $0 z 10$ & $\mathrm{C} 3(\mathrm{Mog})$ & $\begin{array}{l}\text { 1. c } 1449 t \\
\text { 2. deletion of } \\
1911-2426\end{array}$ & $\begin{array}{l}\text { 1. Pro-335 Ser } \\
\text { 2. deletion within the } 3 \text { ' UTR }\end{array}$ \\
\hline$q 126$, oz 142 & $\mathrm{D}(\mathrm{Fog})$ & g 1369 a & Gly-308 Glu \\
\hline$q 266$ & $\begin{array}{l}\text { E (Fog/abn. } \\
\text { oocyte) }\end{array}$ & deletion of $1412-1438$ & amino acids $322-331$ deleted, Ile- $323 \mathrm{Met}$ \\
\hline q343 & F (abn. oocyte) & $\begin{array}{l}\text { insertion after } \\
2164\end{array}$ & insertion of Tc2 in the $3^{\prime}$ UTR \\
\hline
\end{tabular}

Molecular lesions were determined as described in the text and Materials and methods. The numbering of the altered nucleotides is given in Fig. 3. Amino acids affected are numbered according to the predicted protein from the major transcript, represented by the cDNA pLAJl (see text). Phenotypic class designations are defined in Francis et al. (1995a). Both class Al and A2 alleles have a recessive tumorous germ-line phenotype (tum), where presumptive female germ cells exit pachytene and return to mitotic proliferation. Class $\mathrm{Al}$ is null for all aspects of gld-1 function, whereas A2 alleles display gf poisoning activity that results in feminization of the hermaphrodite germ line (see Discussion). Class B alleles show a recessive phenotype in which presumptive female germ cells do not differentiate (undiff.) and are arrested in pachytene. Class $\mathrm{C}$ alleles all result in a recessive masculinization of the germ-line (Mog) phenotype; homozygous hermaphrodites produce a vast excess of sperm and either never switch to oogenesis $(\mathrm{C} 1$ and $\mathrm{C} 2)$ or eventually switch in older adults $|\mathrm{C} 3|$. Class $\mathrm{Cl}$ alleles show a stronger dominant $\mathrm{Mog}$ phenotype than class $\mathrm{C} 2$ alleles, and class $\mathrm{C} 2$ alleles display an undifferentiated phenotype at $15^{\circ} \mathrm{C}$ similar to class B. The Mog phenotype for all class $\mathrm{C}$ alleles is the result of $g f$ poisoning activity. In addition, class $\mathrm{Cl}$ and $\mathrm{C} 2$ alleles have partial loss-of-function defects in directing oocyte development. Class $\mathrm{D}$ alleles show a feminization of the germ line (Fog) phenotype in both hermaphrodites and males; germ cells that would normally develop as sperm instead develop as oocytes. The class E allele shows a recessive abnormal oocyte (abn. oocyte) phenotype, where female germ cells fail to complete oocyte differentiation but undergo meiotic prophase development normally. In addition, the class $\mathrm{E}$ allele has a hermaphrodite-specific Fog phenotype. For both classes $\mathrm{D}$ and $\mathrm{E}$, the Fog phenotypes are the result of $g f$ defects. The class $\mathrm{F}$ allele also displays an abnormal oocyte phenotype but does not have a Fog phenotype. Some class A2 and B alleles are intragenic revertants of the class $\mathrm{C} 1$ Mog mutations (e.g., $q 930 z 50$ ); both the original and a new mutation were found, but only the new mutation is presented. Missense alleles of gld-1 that affect residues conserved among Sam68, GRP33, ZFM1, and GLD-1 (see Fig. 4), are shown with the wild-type amino acid in boldface type.

ing males to make oocytes (Francis et al. 1995a). The two class D mutations ( $q 126$ and oz142) contain identical nucleotide changes resulting in Gly-308 Glu. This mutation alters one of the few amino acids not conserved between GLD-1 and $\mathrm{BO} 280.11 \mathrm{~b}$ in the CGA region (see Fig. 4A). The class E allele $q 266$ also alters amino acids in the CGA region (see above) and, like many of the gld-1 alleles, has a $g f$ effect on hermaphrodite spermatogenesis that results in a Fog phenotype. Unlike the class D alleles, however, q266 does not affect XO males overtly.

In contrast, class $\mathrm{C}$ alleles are rare $g f$ mutations of gld-1 that increase hermaphrodite sperm production [a masculinization of the germ-line (Mog) phenotype]. On the basis of distinct genetic and phenotypic properties
(Francis et al. 1995a) the 11 gld-1(Mog) alleles have been divided into three subclasses $(\mathrm{Cl}, \mathrm{C} 2$, and C3). Homozygous $\mathrm{Cl}$ and $\mathrm{C} 2$ mutants make excess sperm and fail to switch to oogenesis. Genetic tests indicate that these alleles, while having a $g f$ defect for male sex determination (in the hermaphrodite), are partial loss of function for the major role of gld-1 in directing oogenesis. All class $\mathrm{Cl}$ mutations $(q 93, q 62, o z 17, o z 34$, and $o z 35)$ result in Gly-248 Arg, and all class C2 mutations (oz30, $o z 16, o z 29, o z 33$, and oz 70 ) result in Gly-250 Arg. Thus, missense mutations in two absolutely conserved glycine residues in the GSG domain (see Fig. 4A) are responsible for the fully penetrant Mog phenotype [all of the Mog alleles were rare independent isolates that arose at a fre- 


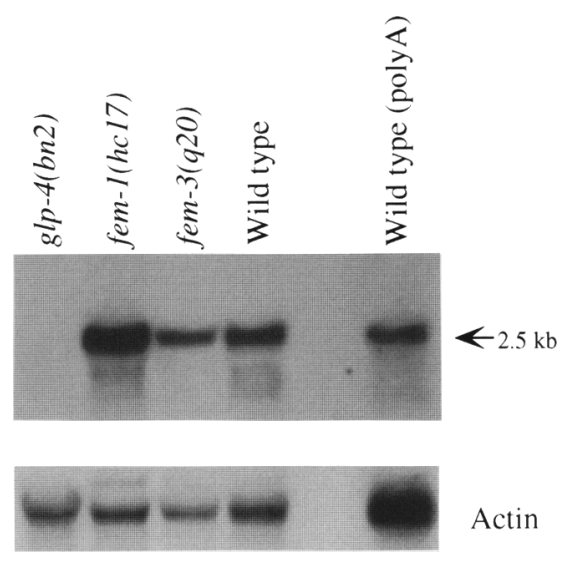

Figure 7. gld-1 RNA expression in the germ line. A Northern blot probed with the cDNA clone pLAJl is shown. The first four lanes contain $\sim 5 \mu \mathrm{g}$ of total RNA from predominantly young adult-stage animals, with the animals in the first three lanes grown at $25^{\circ} \mathrm{C}$ (restrictive temperature for these mutations). gld-1 RNA is easily detectable in total RNA on overnight exposure and is presumably a relatively abundant RNA. The last lane contains $\sim 0.5 \mu \mathrm{g}$ of poly(A)-selected RNA from a mixed developmental stage population of wild-type animals (N2). An act-1-specific probe was used as a control for loading (a gift from L. Schriefer, Washington University, St. Louis, MO|.

quency of $1 \times 10^{-5}$ (Francis et al. 1995a)]. Animals homozygous for the sole $\mathrm{C} 3$ allele $(o z 10)$ produce a vast excess of sperm but sometimes switch to oogenesis and become self-fertile. The oz10 allele contains two mutations: a missense mutation (Pro-335 Ser) and a 515-bp deletion within the $3^{\prime}$ UTR of the gene. This $3^{\prime}$ UTR mutation has an obvious parallel to $g f$ alleles of fem-3, which also contain 3' UTR mutations that produce a Mog phenotype (Ahringer and Kimble 1991); however, interpretation of the oz10 phenotype is confounded by the presence of the missense mutation.

\section{Tissue specificity of gld-1 RNA}

We analyzed gld-1 RNA levels in wild type (Fig. 7). A Northern blot of mixed-stage poly $(\mathrm{A})^{+}$RNA from wild type (N2) shows a single band of $\sim 2.5 \mathrm{~kb}$ when probed with the cDNA clone pLAJ1; no additional bands are seen on extended exposures. In Northern blots of RNA from developmentally staged populations, a $2.5-\mathrm{kb}$ band is also visible in the L3 larval stage and increases in abundance up to the adult stage (A. Jones, unpubl.). This single band presumably represents the two gld-1 transcripts identified by CDNA sequence and RT-PCR analysis.

To examine the tissue specificity of gld-1 RNA, total RNA was analyzed from adult populations of several mutants that affect the germ line. $g l p-4(b n 2)$ is a conditional mutant that makes very few germ cells at the restrictive temperature (Beanan and Strome 1992). The absence of gld-1 transcript in total RNA from $g l p-4|b n 2|$ adults (Fig. 7) suggests that the production of gld-1 RNA is dependent on, and perhaps limited to, the germ line. The 2.5-kb gld-1 RNA band is detected in total RNA from animals with germ lines undergoing both male [fem-3(q20gf); Barton et al. 1987] and female development [fem-1(hc17); Hodgkin 1986], consistent with the sex-nonspecific role of gld-1 in premeiotic proliferation (Francis et al. 1995b).

\section{Analysis of the two gld-1 transcripts}

Alternative splicing of gld-1 RNA produces transcripts whose predicted protein products differ by 3 amino acids. The alternative splice product of $g l d-1$ is predicted to add Leu-Leu-Lys within the GSG domain (see Fig. 4A). Because these changes could add functionality or change the specificity of RNA binding (e.g., Gorlach et al. 1994) or possibly eliminate function (e.g., Liang et al. 1991), we wanted to address whether the alternative splice was regulated developmentally or sex specific. To do this we undertook radioactive RT-PCR using RNA samples in which gld-1 RNA is present at detectable levels on Northern blots. In all developmental stages tested, as well as in RNA samples from adult hermaphrodite animals that were making only sperm $[f e m-3(q 20 g f)]$ or only oocytes [fem-1(hc17)], the smaller RT-PCR product is present at roughly two to three times the amount of the larger product (Fig. 8). Thus, we found no evidence that

Figure 8. Analysis of the relative abundance of the two alternatively spliced products. The radioactive products of RT-PCR are shown (see text; Materials and methods), separated on a denaturing polyacrylamide gel and autoradiographed. Three PCR cycle points within the linear range of amplification were taken for each RNA sample tested, and quantitation of each band was performed. The ratio of the smaller product to the larger product calculated for each

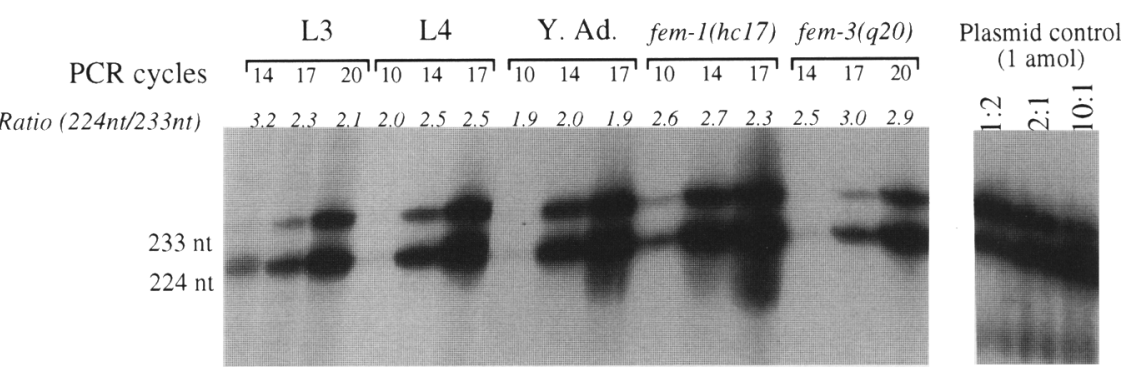
PCR cycle point is shown. The plasmid control reactions were included to demonstrate that known ratios of input DNA gave an equivalent output ratio in the assay. The control reactions were for 20 cycles of amplification, starting with 1 amole of DNA containing different ratios of two cDNA plasmid clones representing the two different splice products. 


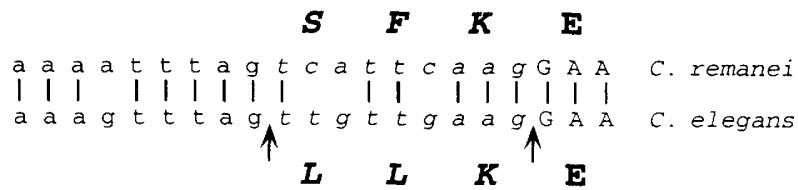

Figure 9. A comparison of the two splice sites for exon 6 in $C$. elegans and C. remanei. Genomic sequence for C. elegans corresponds to nucleotides 1155-1175 (see Fig. 3). Bars match identical nucleotides; and arrows indicate the two splice sites that are used. Translations of the coding regions are shown above and below the respective sequences, and both the nucleotides and amino acids are italicized for the longer transcript.

selection of either splice site is developmentally regulated. None of the gld-1 mutations described above affect the region of alternative splicing.

Interestingly, we found evidence that both of these splice sites are conserved and used in splicing in the related species C. remanei (see Materials and methods). As shown in Figure 9, the nucleotides around each splice site are conserved but the three additional amino acids encoded by the second splice site are not conserved. Because both of the spliced forms are present in C. remanei (a male/female species), we think it is unlikely that alternative splicing is used to control the gld-1 activity that promotes hermaphrodite spermatogenesis. We do not have information about the relative abundance of each of these transcripts in C. remanei.

\section{Discussion}

\section{gld-1 has a tumor suppressor function in vivo}

The gld-1 gene functions as a female germ cell-specific tumor suppressor. XX animals homozygous for the genetic null allele gld-1 $(q 485)$ exhibit a phenotype in which germ cells fail to undergo oogenesis and proliferate ectopically, forming a germ-line tumor (Francis et al. 1995a). The results of the molecular analysis of gld. 1(q485) are consistent with the genetic interpretation of this allele as null for the locus: $q 485$ contains an aminoterminal frameshifting deletion and fails to make a gene product (A. Jones and T. Schedl, unpubl.).

\section{GLD-1 contains evolutionarily conserved domains}

The predicted GLD-1 protein has extensive similarity over a third of its length with two proteins: Sam68 and GRP33. We call this region, comprising $\sim 170$ amino acids, a GSG domain (see Fig. 4). GRP33 is a putative hnRNP from brine shrimp (Cruz-Alvarez and Pellicer 1987) but has not been studied extensively since its identification. The mouse phosphoprotein Sam68 associates with $\mathrm{Src}$ in a cell cycle-dependent manner (Fumagalli et al. 1994; Taylor and Shalloway 1994) and is thought to be nearly identical to the sequence reported for GAP-associated p62 from humans [see Courtneidge and Fumagalli (1994) for clarification of nomenclature]. Sam68 contains several regions with the potential to interact with the
Src homology regions SH2 and SH3 (Weng et al. 1994; Richard et al. 1995); however, these regions of Sam68 lie outside the GSG domain and are not found in GLD-1 or GRP33.

The importance of the GSG domain to the in vivo function of GLD-1 is revealed by 16 independent gld-1 missense mutations that occur throughout this region of the protein, many in absolutely conserved residues /see Table 1; Fig. 4). These mutations affect gld-1 function in various ways, resulting in one of three phenotypic classes of gld-1 mutations: Missense mutations in Gly227 abolish the essential function of gld-1 in directing oogenesis and suppressing tumor formation (phenotypic class A2); mutations in either Gly-248 or Gly-250 result in a $g f$ defect that leads to the masculinization of the hermaphrodite germ line (Mog phenotype: classes $\mathrm{Cl}$ and $\mathrm{C2}$ ); and mutation in any one of four residues in the GSG domain can suppress class $\mathrm{Cl}$ mutations intragenically to produce a loss-of-function phenotype (either mutant class $\mathrm{A} 2$ or $\mathrm{B}$ ).

Another C. elegans gene, $\mathrm{BO} 280.1 \mathrm{lb}$, encodes part of the GSG domain (see Fig. 4B). Within this partial GSG domain, GLD-1 is more similar to Sam68 (41 amino acids identical) than it is to $\mathrm{BO} 280.1 \mathrm{lb}$ ( 35 amino acids identical). However, a second region of GLD-1 and $\mathrm{BO} 280.1 \mathrm{lb}$ is highly conserved $168 \%$ identical over 22 amino acids). This small region, which we refer to as the CGA region, is just carboxy-terminal to the GSG domain and apparently not found in Sam68 and GRP33. This region, as well as a partial GSG domain, is also found in ZFMl, a gene that is tightly linked to multiple endocrine neoplasia type 1 (MEN1) in humans (Toda et al. 1994). Like the GSG domain, the CGA region is important for GLD-1 function, as several gld-1 mutations affect it (refer to Table 1; and Fig. 4): An intragenic mutation in Glu-310 suppresses the class $\mathrm{Cl}$ mutant defect, with the resulting double mutant having a tumorous phenotype (phenotypic class A2); mutation of Gly-308 results in a gf defect leading to a feminization of the germ-line (Fog) phenotype in both the hermaphrodite and male but does not disrupt oocyte differentiation (class D); finally, deletion of the last 4 amino acids of the CGA region results in a defect in oogenesis as well as a $g f$ defect that results in a hermaphrodite-specific Fog phenotype (class E).

\section{The gld-1 GSG domain may be involved in RNA binding}

A potential biochemical function for the GSG domain is suggested by a general in vitro RNA-binding activity for Sam68 (Wong et al. 1992; Taylor and Shalloway 1994; Wang et al. 1995). This ability to bind RNA may be attributable in part to the presence of a single $\mathrm{KH}$ motif within the larger region of similarity (see Fig. 4B). A number of other proteins that contain the $\mathrm{KH}$ motif have been implicated in RNA metabolism (Gibson et al. 1993). In most cases, the KH motif is present in multiple copies (Gibson et al. 1993; Siomi et al. 1993b). GSG domain proteins, however, contain a single $\mathrm{KH}$ motif. Furthermore, the single $\mathrm{KH}$ motifs of GSG domain proteins 
are more similar to each other than to any other $\mathrm{KH}$ motif (see Fig. 4). The high degree of similarity between GSG domain proteins, as well as a comparison of GSG domain proteins to other $\mathrm{KH}$ motif-containing proteins in overall structure, provides additional support for the assertion that the GSG domain proteins represent a specialized family of $\mathrm{KH}$ motif-containing proteins (Gibson et al. 1993). Conserved regions of the GSG domain outside of the KH motif may themselves be critical for modulating an RNA-binding activity of the $\mathrm{KH}$ motif (i.e., affecting the binding affinity or specificity). Alternatively, these regions may be involved in contacts with other proteins.

Potential RNA targets for binding by KH motif-containing proteins have not been well characterized. Specific RNA targets for Sam68 binding have not been reported. $F M R-1$ has been demonstrated to bind its own transcript but has also been reported to bind $\leqslant 4 \%$ of all mRNA from human brain, implying a general nonspecific RNA-binding ability (Ashley et al. 1993). However, a number of hnRNPs, originally thought to be nonspecific RNA-binding proteins, have been found to bind to specific targets with high affinity (e.g., Dreyfuss et al. 1993; Burd and Dreyfuss 1994; Gorlach et al. 1994). In addition, in vitro experiments with hnRNP K suggest that the KH motif may also mediate DNA binding (Takimoto et al. 1993). GLD-1 protein appears to be absent from the nucleus as determined by antibody staining (A. Jones and T. Schedl, in prep.). Therefore, if GLD-1 is an RNA-binding protein, it most likely functions in the cytoplasm to control translation or mRNA stability.

Mutations in the $\mathrm{KH}$ motif of GLD-l eliminate the major in vivo function of GLD-1 in directing oogenesis. Two different substitutions of an absolutely conserved glycine in the $\mathrm{KH}$ motif of gld-1 (see Fig. 5) result in the formation of germ-line tumors that are similar to those found in the genetic null allele $q 485$ (Francis et al. 1995a). Thus, missense mutations in the KH motif of GLD-1 result in loss of the GLD-1 tumor suppressor function in vivo.

\section{gld-1 mutant protein may poison other gene products}

Many gld-1 alleles behave in a dominant manner with respect to the nonessential role of gld-1 in promoting hermaphrodite spermatogenesis. The presence or absence of sperm in a hermaphrodite is easily scored, and the effect of various gld-1 alleles on this function was quantified (Francis et al. 1995a). The analysis revealed a weak haploinsufficient Fog phenotype for large deletions of the entire locus as well as the class Al genetic null allele $q 485$.

Significantly higher penetrance of the Fog phenotype was observed for all other class A alleles (designated class A2), indicating that although they are nonfunctional for the major role of gld-1 in directing oogenesis, they exhibit $g f$ activity that results in a poisoning or a dominant-negative effect on germ-line sex determination (Francis et al. 1995a). Interestingly, the class A2 alleles that possess the strongest $g f$ activity are the three alleles with missense mutations in the $\mathrm{KH}$ motif (oz89, $q 930 z 55$, and q361). We believe that the simplest explanation for the in vivo behavior of the gld-1 KH mutations is that stable protein is made, but the portion of GLD-1 that carries out the major functions of the protein is catalytically or structurally inactive. The $g f$ character of the KH motif mutants might result from stable mutant protein either titrating out a limited supply of a factor necessary for male sex determination or poisoning a GLD-1 multimer. We believe this effect involves the poisoning of other gene products because, unlike the gld-1 (null) mutation, $\mathrm{KH}$ motif mutations can cause tumor formation in XO male germ lines (R. Francis and $T$. Schedl, unpubl.).

Other class A2 alleles that are predicted to produce little or no stable gld-1 product show a less penetrant Fog phenotype than the $\mathrm{KH}$ motif mutations. These mutations include $0 z 127$, a small out-of-frame deletion, as well as four nonsense mutations $(q 365, q 268, q 495$, and $q 93 \mathrm{oz} 49 \mid$. These alleles may produce a small amount of gld-1 product that, like the product produced by the $\mathrm{KH}$ mutation alleles, might poison hermaphrodite spermatogenesis. Concordant with this idea, there is a correlation between the level of $g f$ poisoning and nonsense mutation position: The most carboxy-terminal nonsense mutation, $q 930 z 49$, has a more penetrant phenotype than does q268, which in turn has a more penetrant phenotype than $q 365$, the amino-terminal mutation. The poisoning interaction seen with the class A2 mutations may be attributable to protein-protein rather than protein-RNA interactions, as the $q 365$ mutations should generate a GLD-1 protein that does not contain a complete $\mathrm{KH}$ motif. Candidates for interacting proteins include the products of any of the fem genes (Hodgkin 1986), fog-1(Barton and Kimble 1990), or fog-3 (Ellis and Kimble 1995), all of which promote male germ-line sex determination. The gf class D and E mutations could produce a Fog phenotype by a similar mechanism.

Interestingly, $\mathrm{KH}$ motif missense mutations in FMR-1 from humans (De Boulle et al. 1993) and the Bic-C gene in Drosophila (Mahone et al. 1995) also lead to a phenotype that is more severe than the null phenotype. These mutant proteins could poison other molecules in a manner analogous to that of gld-1 KH motif mutations.

The $g$ f class $\mathrm{C}$ mutations increase spermatogenesis in hermaphrodites, possibly by interfering with the gene products required for the switch from spermatogenesis to oogenesis (Francis et al. 1995a). In addition, class $\mathrm{Cl}$ and C2 Mog mutants behave as partial loss-of-function mutations with respect to oogenesis (Francis et al. 1995b). The molecular lesions in the class $\mathrm{Cl}$ and $\mathrm{C} 2$ Mog mutants occur in amino acids absolutely conserved among the GSG domain proteins (see Fig. 4A), adiacent to the $\mathrm{KH}$ motif. Given the position of these mutations in relation to the $\mathrm{KH}$ motif, the class $\mathrm{Cl}$ and $\mathrm{C} 2 \mathrm{Mog}$ mutations might act by failing to regulate the activity of the KH motif properly. Consistent with this hypothesis is the finding that the allele $q 930 z 55$, which corresponds to the cis double mutant of the Mog allele $q 93$ (class C1) and the tumorous allele $o z 89$ (class A2), is phenotypi- 
cally indistinguishable from the oz89 single mutant, even in its $g f$ feminizing defect (Francis et al. 1995a). Thus, the $\mathrm{KH}$ motif missense mutation appears to suppress the $q 93$ missense mutation completely. For this reason, the $g f$ activity of class $\mathrm{Cl}$ alleles must in some way act through a functional $\mathrm{KH}$ motif.

\section{GLD-1 as a regulator of germ-line development}

GLD-1 might function by regulating mRNA stability or translation. By functioning in this manner, GLD-1 could control aspects of germ-line development by acting as a specific regulator of a few key RNAs or a more general regulator of many RNAs. Germ-line translational control in C. elegans has been shown to be an important mode of regulating proliferation $[(g l p-1)$; Evans et al. 1994], male development [(fem-3); Ahringer and Kimble 1991], and female development [(tra-2); Goodwin et al. 1993]. Although these genes could be regulated ostensibly by GLD-1, none stand out as likely targets: gld-1 tumors still form in the absence of $g l p-1$ product (Francis et al. 1995b), indicating that tumor formation is not caused by a failure to regulate $g l p-1$ activity; epistasis analysis revealed that gld-1 acts downstream of tra-2 (Francis et al. 1995b); and masculinization in the gld-1 class $\mathrm{Cl}$ Mog allele may not result from increased fem-3 activity (Ellis and Kimble 1995).

If GLD-1 functions as a translational regulator, how might it act as a female germ-line tumor suppressor? The mos proto-oncogene provides an example of a cell cycle control factor that is regulated translationally during meiotic prophase. In Xenopus oocytes, the mos serinethreonine protein kinase is needed for activation of maturation promoting factor in meiosis I and for meiosis II arrest (Yew et al. 1993). Although mos mRNA synthesis begins early in oogenesis, it is only translated in mature oocytes after the stimulus for meiotic maturation (Sagata et al. 1988). Furthermore, inappropriate expression of mos can result in tumor formation (Yew et al. 1993). In gld-1 (null) mutants, mRNAs encoding factors that are synthesized for use late in oocyte development and are capable of promoting mitosis (such as mos) might be translated inappropriately. Alternatively, loss of gld-1 activity might result in the inappropriate translation of mitotic factors packaged in the oocyte for embryonic cell divisions. Such ectopic mitotic activity early in oocyte development might then result in an exit from meiotic prophase, a return to mitotic proliferation, and subsequent tumor formation.

\section{GLD-1, Sam68, and mitosis}

gld-1 has a demonstrated role in vivo for regulating $\mathrm{mi}$ totic activity negatively during pachytene of meiotic prophase (Francis et al. 1995a) and a nonessential, probably redundant role in regulating proliferation negatively in premeiotic germ cells (Francis et al. 1995b). Biochemical experiments show that the mammalian protein Sam68 interacts with Src in a cell cycle-specific manner (Fumagalli et al. 1994; Taylor and Shalloway 1994) and is phosphorylated on tyrosine during mitosis (Fumagalli et al. 1994/. Given that both Sam68 and GLD-1 contain GSG domains, it is tempting to speculate that both molecules might be involved in the regulation of mitosis in similar ways. However, the region of Sam68 that binds to Src shows no similarity to GLD-1. Interestingly, tyrosine phosphorylation of the carboxy terminus of Sam68 may regulate its RNA-binding activity (Wang et al. 1995). Regions outside of the GSG domain could regulate GLD-1 activity in an analogous manner. The similarity between GLD-1 and Sam68 within the GSG domain suggests that if these two proteins do have a regulatory role in mitosis in common, targets for interaction with the GSG domain (either proteins or RNAs) might be conserved across phyla as well.

\section{Materials and methods}

Physical mapping of the gld-1 gene

Genetic mapping placed the gld-1 locus in relation to three multilocus deletions, $n D f 24, n D f 25$, and $o z D f 5$ (Fig. 2A; Francis et al. 1995a). Using sequence information from various clones spanning this region, PCR assays were developed and used on individual homozygotes from each deletion (Barstead et al. 1991). PCR primer sets were derived from sequence of the cosmids MO2B2 and ZK1014 [primers MO2B2 (a and b) and $\mathrm{ZK} 1014$ ( $\mathrm{a}$ and $\mathrm{b}$ ); Y. Kozono, pers. comm.) and sequence of the LRP gene, which resides on cosmid F29D11 (primers F29D11 a and $\mathrm{b}$; Yochem and Greenwald 1993). These assays placed gld-1 between the cosmid clones F29D11 and ZK1014 on the physical map, and individual cosmids in this interval were used as probes on Southern blots to identify gld-1 RFLPs (Fig. 2B; Coulson et al. 1988).

Transgenic experiments provide results that are consistent with identification of the gld-1 gene. Six independent extrachromosomal array-containing lines were generated by microinjecting pAJ37 (wild-type gld-1 at $10 \mu \mathrm{g} / \mathrm{ml}$ ) and the dominant rolling marker plasmid pRF4 $(100 \mu \mathrm{g} / \mathrm{ml}$; Mello et al. 1991). All stable lines produced variable dominant phenotypes similar to gld-1 loss-of-function (ectopic proliferation, pachytene arrest, abnormal ooctyes, and feminization of the germ line) in a wildtype background, and all failed to rescue the tumorous phenotype after crossing into gld-1 (q485) (A. Jones unpubl.). Similarly, wild-type transgenes of another germ-line locus, glp-1, can produce a variable dominant $g l p-1$ loss-of-function germ-line phenotype in a wild-type background (A. Fire, pers. comm.). The basis of these results is not understood presently.

\section{Nucleic acid preparation and analysis}

Standard methods for manipulation of DNA and RNA were used (Ausubel et al. 1991). Sequence was determined for the majority of the $6.8-\mathrm{kb}$ subclone pAJ37 by methods similar to those described in Wilson et al. (1994). RNA was prepared from developmentally staged nematode populations as described (Meyer and Casson 1986; Goetinck and Waterston 1994).

\section{Isolation and analysis of cDNA clones}

Clones $\left(1 \times 10^{5}\right)$ from a $\lambda Z A P$ cDNA library la gift from $R$. Barstead, Oklahoma Medical Research Foundation, Oklahoma City) were screened using a $1.0-\mathrm{kb}$ EcoRI-HindIII fragment as a probe (see Fig. 2C). Five clones were characterized by restriction 
analysis and sequencing. Three appear to be identical and near full length, with the 5 ' end containing the last five nucleotides of the C. elegans trans-spliced leader SLl (Krause and Hirsh 1987). One of these clones, pLAJ1, was sequenced entirely.

Analysis of the $5^{\prime}$ end of the gld-1 transcript was performed using the 5' RACE system (GIBCO/BRL) according to the manufacturer's instructions. Starting material was $1 \mu \mathrm{g}$ of mixedstage total RNA, with primer AIgr29a used to prime reverse transcription. In amplification reactions with the supplied anchor primer, both primers AJgr28 and AJgr23 gave single-band products as assayed on agarose gels. Amplification products were cloned, and the $5^{\prime}$ ends of 28 independent cDNA clones were sequenced: 23 contained the full-length trans-spliced leader SL1, and 5 terminated at different points within the coding region. To look for additional differentially spliced products (other than the alternate splice described in Results), equivalent amounts of RNA from each developmental stage were combined and reverse transcribed with random primers as described below for analysis of the two known spliced forms. PCR analysis of this sample using numerous combinations of gld-1-specific primers did not provide evidence for additional alternative splicing of the gld-1 transcript (data not shown).

\section{Characterization of $\mathrm{BO} 280.11 \mathrm{~b}$}

A BLAST search with gld-1 identified similarity to the product of the predicted gene $\mathrm{BO} 280.11$ on the C. elegans cosmid BO280 (GenBank accession no. U10438). This sequence was used to make primers for 5 '-RACE analysis as described above for gld-1. Reverse transcription was primed with AJgotr32, and the CDNA was amplified with AJgotr30 and anchor primer. A predominant band of $\sim 600$ bp was cloned. Four independent clones were sequenced, none of which contained a trans-spliced leader sequence. However, two clones with inserts of -600 bp had identical 5 ' ends. The sequence of these clones revealed two important differences from the predicted splicing pattern. First, the 5 '-RACE clones do not contain the first five predicted exons of BO280.11, which code for a potential tyrosine phosphatase. Second, some of the remaining five exons use different splice sites than predicted. The resulting gene, which we refer to as BO280.1 lb, has the following structure (numbered according to cosmid BO280): exon 1 (34089-33988); exon 2 (33936-33851); exon 3 (33798-33474); exon $4(33425-33328)$; exon 5 (3328133049 | We believe the $\mathrm{BO} 280.11 \mathrm{~b}$ cDNAs represent an independent translational unit, as exon 1 contains stop codons in each reading frame before the putative initiator methionine codon starting at 34027 . We have no information about the $3^{\prime}$ end of $\mathrm{BO} 280.11 \mathrm{~b}$.

\section{Isolation of gld-I from C. remanei}

To obtain sequence from the $C$. remanei gld-1 gene, we used the primer pair AJgf16 and AJgf20 in low annealing temperature PCR reactions on C. remanei genomic DNA. Using the sequence of the amplification product, we designed the C. rema. nei-specific primers AIRgr15, AJRgr16, and AJRgf16. 5'-RACE cloning and sequencing, as described above, was performed on C. remanei RNA using AJRgrl6 and AJRgr15. Several clones that contained a trans-spliced leader identical to the $C$. elegans trans-spliced leader SLl (Krause and Hirsh 1987) were sequenced completely. Additional sequence was obtained from the RT-PCR product of primers AJRgfl 6 and AJcrll.

The genomic sequence between exons 5 and 6 in C. remanei was determined from the amplification product of primers AJRgf 16 and AJcr8 on genomic DNA /sequence around the splice sites is shown in Fig. 91. On the basis of this sequence, we constructed the primer AJremaltf, which contains the last 12 nucleotides of exon 5 and the first 6 nucleotides of the alternate splice. AJremaltf, in combination with AJcr8, AJRCcr9, or AJcrll gave single-band products in PCR on reverse-transcribed C. remanei RNA (data not shown), providing evidence that this splice site is used in C. remanei.

\section{Analysis of gld-1/ozl 16) splicing}

For the RT-PCR analysis of gld-1(oz116), RNA was isolated from the strain nDp4; unc-13(e51) gld-1(oz116). Primer AJcr20 was used to prime reverse transcription of $1 \mu \mathrm{g}$ of total RNA. PCR was performed using primers AJcrl9 and AJrt2, and the products were cloned and sequenced. Twenty-six independent clones were sequenced; 18 had the predicted wild-type sequence through the splice site junction at the final exon, and 8 had a 2-bp deletion relative to wild-type cDNAs, suggesting that these clones represent aberrant splice products that use an $A G$ acceptor 2 nucleotides downstream of the normal acceptor. The wild-type clones may either represent RNA from the wild-type copy of gld-1 on $n D p 4$ and/or correct splicing of mutant oz116 RNA similar to that seen by Aroian et al. (1993).

\section{RT-PCR analysis of gld-1 RNA}

Approximately $5 \mu \mathrm{g}$ of each RNA sample was reverse transcribed with 200 units of Superscript RT (GIBCO/BRL) at $42^{\circ} \mathrm{C}$ for $30 \mathrm{~min}$ with $15 \mu \mathrm{g}$ of random hexamer primers (GIBCO/ BRL|. One-twentieth of each reaction was PCR amplified directly using primers AJgf $20\left({ }^{32} \mathrm{P}\right.$ end-labeled) and AJRCcr9. The amplification cycle profile was $94^{\circ} \mathrm{C}$ for $30 \mathrm{sec}, 64^{\circ} \mathrm{C}$ for $30 \mathrm{sec}$, and $72^{\circ} \mathrm{C}$ for $45 \mathrm{sec}$, ending with $7 \mathrm{~min}$ at $72^{\circ} \mathrm{C}$ after the final cycle. Separate reactions were done at different numbers of cycles to determine the linear range of amplification for each sample. Amplification products were separated on denaturing polyacrylamide gels $(5 \%, 7 \mathrm{~m}$ urea). Quantitation was performed using a PhosphorImager (Molecular Dynamics). To show that both spliced products would amplify at the same efficiency, experiments were first done on CDNA plasmid clones of known concentration (Fig. 8; data not shown). Because of the sensitivity of the assay, a no-DNA control was always included and all RNA samples were tested for contamination by performing the reaction on RNA that had not been reverse transcribed.

\section{Allele sequencing}

Five adult animals homozygous for each allele of gld-1 were processed essentially as described in Williams et al. (1992). PCR was performed on these samples using one of three primer pairs to generate DNA for sequencing (AJgf9/AJgr23, AJgf21/AJgr32, or AJgf27/AIgr37). Of each product, 25-50 ng was sequenced using ${ }^{32} \mathrm{P}$-end-labeled primers in a cycle sequencing reaction (Craxton 1991). The genomic DNA containing the gld-1 coding region was sequenced completely for all alleles with the exception of Mog alleles oz30,oz33, $q 62, o z 34, o z 16$, and oz70, most of which were only sequenced with AJgr 21 and confirmed on the opposite strand with AIgf18. In addition, six alleles ( $q 93$, $q 126, q 268, q 930 z 50, o z 10$, and $o z 35$ ) were sequenced through the 810-bp 3' UTR. For $q 343, \sim 200$ bp of sequence from each end of the $2.3-\mathrm{kb}$ insertion was obtained using the primers AJgf 28 and AJgr32. A TA target site duplication occurred at the site of insertion, as has been described previously for $\mathrm{Tc} 2(\mathrm{Ru}-$ volo et al. 1992). All mutations were confirmed on the opposite DNA strand. 


\section{Oligonucleotide primers used}

The following oligonucleotides were used for this work, with the corresponding genomic sequence (numbered according to the sequence in Fig. 3) in parentheses; descending numbers indicate that the primer is on the opposite strand: AJgf $(7-27)$; AJgf10 (178-201); AJgf14 (521-540); AJgr14 (550-539); AJgf16 (678-695); AJgr17 (813-796); AJgf18 (939-958); AJgr20 (10891068); AJgf20 (1068-1088); AJgr21 (1182-1164); AJcr8 (12091193); AJgf21 (1206-1223); AJrt2 (1301-1316, 1362-1364); AJRCcr9 (1377-1362, 1316-1314); AJgr23 (1442-1424); AJgf24 (1501-1520); AJcrll (1634-1618, 1574-1571); AJgr25a (15891568); AJgf27 (1814-1831); AJgr27 (1831-1814); AJgf28 (1852-1871); AJgr29a (2055-2034); AJgf30 (2112-2131); AJgr32 (2319-2301); AJgf33 (2375-2394); AJcr19 (2478-2459); AJcr20 (2530-2516); AJgr37 (2798-2781). Additional oligonucleotides used were MO2B2a GCTCAGACCGCAGTTTCAG, MO2B2b GAGCAGTCATGAGTGGATTG, F29D11a CATGGAGGTGAATGTACGTGCC, F29D11b CAGAATGAGCAAGACGATCAGTC, AJremaltf GACAAGTCAAAGTCATTC, AJRGr15 GCGGAATTCGGATCCTACACGAACACGACCG, AJRgf16 GCGGAATTCGGATCCAAGATCTATGTCCCAAAG, AJRgr 16 GCGGGATCCTCGAGTCGTTCTTTGGGACATAG, AJgotr32 GCGAATTCGGATCCTTATTTGAGTGTTCCTTC, and AJgotr30 GCGAATTCGGATCCATCTTTTGTACATCCTTTTCC.

\section{Note added in proof}

The GSG domain and the CGA region of the GLD-1 protein are quite similar (58\% identical, $82 \%$ similar over 192 amino acids) to part of the mouse quaking gene product (T.A. Ebersole, Q. Chen, M.J. Justice, and K. Artzt, pers. comm.). All eight of the amino acids in which gld-1 missense mutations are found are conserved between GLD-1 and the predicted quaking protein.

\section{Acknowledgments}

We are most grateful to Bob Clifford and Ross Francis for continuous help in all aspects of the construction of the manuscript. We are also appreciative of comments on the manuscript from Patty Kuwabara and Bethany Westlund. We are indebted to Yuko Kozono and John Yochem for providing sequence for PCR mapping as well as Ratna Shownkeen and Alan Coulson for providing cosmids. We thank Yueping Zhang for technical assistance. Protocols advice, vectors, reagents, and discussion were freely provided by Laura Wilson Berry, Jim McCarter, Kouichi Iwasaki, Jim Waddle, Sue Goetinck, Bob Barstead, Larry Schriefer, Bert Schrank, Pam Hoppe, LaDeana Hillier, Rick Wilson, Andrey Shaw, Kim Wieties-Clary, Phil Green, Steve L'Hernault, and Bob Waterston and are greatly appreciated. We especially thank John Lye for help with fluorescent sequencing and Don McEwen for help with quantitation. This work was supported by U.S. Public Health Service grant HD25614 and a Basil O'Connor Starter Research grant 5-809 to T.S., and a predoctoral fellowship from the National Science Foundation to A.J.

The publication costs of this article were defrayed in part by payment of page charges. This article must therefore be hereby marked "advertisement" in accordance with 18 USC section 1734 solely to indicate this fact.

\section{References}

Ahringer J. and J. Kimble. 1991. Control of the sperm-oocyte switch in Caenorhabditis elegans hermaphrodites by the fem-3 3' untranslated region. Nature 349: 346-348.
Altschul, S.F., W. Gish, W. Miller, E.W. Myers, and D.J. Lipman. 1990. Basic local alignment search tool. I. Mol. Biol. 215: 403-410.

Aroian, R.V., A.D. Levy, M. Koga, Y. Ohshima, J.M. Kramer, and P.W. Sternberg. 1993. Splicing in Caenorhabditis elegans does not require an AG at the 3 ' splice acceptor site. Mol. Cell. Biol. 13: 626-637.

Ashley, C.T., K.D. Wilkinson, D. Reines, and S.T. Warren. 1993. FMR 1 protein: Conserved RNP family domains and selective RNA binding. Science 262: 563-566.

Ausubel, F.M., R. Brent, R.E. Kingston, D.D. Moore, J.G. Seidman, J.A. Smith, and K. Struhl, eds. 1991. Current protocols in molecular biology. Greene/John Wiley, New York.

Barstead, R.J., L. Kleiman, and R.H. Waterston. 1991. Cloning, sequencing, and mapping of an alpha-actinin gene from the nematode Caenorhabditis elegans. Cell Motil. Cyto. 20: 6978.

Barton M.K. and J. Kimble. 1990. fog-1, a regulatory gene required for specification of spermatogenesis in the germ line of Caenorhabditis elegans. Genetics 125: 29-39.

Barton, M.K., T.B. Schedl, and J. Kimble. 1987. Gain-of-function mutations of fem-3, a sex-determination gene in Caenorhabditis elegans. Genetics 115: 107-119.

Beanan, M.J. and S. Strome. 1992. Characterization of a germline proliferation mutation in C. elegans. Development 116: $755-766$.

Benian G.M., S.W. L'Hernault, and M.E. Morris. 1993. Additional sequence complexity in the muscle gene, unc-22, and its encoded protein, twitchin, of Caenorhabditis elegans. Genetics 134: 1097-1104.

Burd, C.G. and G. Dreyfuss. 1994. RNA binding specificity of hnRNP Al: Significance of hnRNP Al high-affinity binding sites in pre-mRNA splicing. EMBO I. 13: 1197-1204.

Clifford, R., R. Francis, and T. Schedl. 1994. Somatic control of germ cell development in Caenorhabditis elegans. Semin. Dev. Biol. 5: 21-30.

Coulson, A., R. Waterston, J. Kiff, J. Sulston, and Y. Kohara. 1988. Genome linking with yeast artificial chromosomes. Nature 335: 184-186.

Courtneidge, S. and S. Fumagalli. 1994. A mitotic function for Src? Trends Cell Biol. 4: 345-347.

Craxton, M. 1991. Linear amplification sequencing, a powerful method for sequencing DNA. Methods: Companion Methods Enzymol. 3: 20-26.

Cruz-Alvarez, M. and A. Pellicer. 1987. Cloning of full-length complementary DNA for an Artemia salina glycine rich protein. J. Biol. Chem. 262: 13377-13380.

De Boulle, K., A.J.M.H. Verkerk, E. Reyniers, L. Vits, J. Hendrickx, B. VanRoy, F. VanDenBos, E. deGraaff, B.A. Oostra, and P.J. Willems. 1993. A point mutation in the FMR-1 gene associated with fragile X mental retardation. Nature Genet. 3: 31-35.

Delahodde, A., A.M. Becam, L. Perea, and C. Jacq. 1986. A yeast protein HX has homologies with the histone H2AF expressed in chicken embryo. Nucleic Acids Res. 14: 92139214.

Dreyfuss, G., M.J. Matunis, S. Piñol-Roma, and C.G. Burd. 1993. hnRNP proteins and the biogenesis of mRNA. Annu. Rev. Biochem. 62: 289-321.

Ellis, R.E. and J. Kimble. 1995. The fog-3 gene and regulation of cell fate in the germ line of Caenorhabditis elegans. Genetics 139: 561-577.

Evans T.C., S.L. Crittenden, V. Kodoyianni, and J. Kimble. 1994. Translational control of maternal glp-1 mRNA establishes an asymmetry in the C. elegans embryo. Cell 77: 183-194. 
Fisher C.W., C.R. Fisher, J.L. Chuang, K.S. Lau, D.T. Chuang, and R.P. Cox. 1993. Occurrence of a 2-bp (AT) deletion allele and a nonsense (G-to-T) mutant allele at the E2 (DBT) locus of six patients with maple syrup urine disease: Multipleexon skipping as a secondary effect of the mutations. Am. I. Hum. Gen. 52: 414-424.

Francis, G.R., M.K. Barton, J. Kimble, and T. Schedl. 1995 a. gld-1, a tumor suppressor gene required for oocyte development in C. elegans. Genetics 139: 579-606.

Francis, G.R., E. Maine, and T. Schedl. 1995b. Analysis of the multiple roles of gld-1 in germline development: Interactions with the sex determination cascade and the glp-1 signaling pathway. Genetics 139: 607-630.

Frohman, M.A., M.K. Dush, and G.R. Martin. 1988. Rapid production of full length cDNAs from rare transcripts: Amplification using a single gene-specific oligonucleotide primer. Proc. Natl. Acad. Sci. 85: 8998-9002.

Fumagalli, S., N.F. Totty, J.J. Hsuan, and S.A. Courtneidge. 1994. A target for Src in mitosis. Nature 368: 871-874.

Gibson, T.J., J.D. Thompson, and J. Heringa. 1993. The KH domain occurs in a diverse set of RNA-binding proteins that include the antiterminator NusA and is probably involved in binding to nucleic acid. FEBS Lett. 324: 361-366.

Goetinck, S. and R.H. Waterston. 1994. The Caenorhabditis elegans muscle-affecting gene unc-87 encodes a novel thin filament-associated protein. J. Cell Biol. 127: 79-93.

Goodwin E.B., P.G. Okkema, T.C. Evans, and J. Kimble. 1993. Translational regulation of tra-2 by its $3^{\prime}$ untranslated region controls sexual identity in C. elegans. Cell 75: 329-339.

Gorlach, M., C.G. Burd, and G. Dreyfuss. 1994. The determinants of RNA-binding specificity of the heterogeneous nuclear ribonucleoprotein C proteins. I. Biol. Chem. 269: 23074-23078.

Hartwell, L.H. and M.B. Kastan. 1994. Cell cycle control and cancer. Science 266: 1821-1828.

Henikoff, S. and J.G. Henikoff. 1993. Performance evaluation of amino acid substitution matrices. Proteins Struct. Funct. Genet. 17: 49-61.

Higgins, D.G., A.J. Bleasby, and R. Fuchs. 1992. CLUSTAL V: Improved software for multiple sequence alignment. Comp. Appl. Biosci. 8: 189-191.

Hodgkin J. 1986. Sex determination in the nematode C. elegans: Analysis of tra-3 suppressors and characterization of fem genes. Genetics 114: 15-52.

Krause, M. and D. Hirsh. 1987. A trans-spliced leader sequence on actin mRNA in C. elegans. Cell 49: 753-761.

Kreidberg J.A., H. Sariola, J.M. Loring, M. Maeda, J. Pelletier, D. Housman, and R. Jaenisch. 1993. WT-1 is required for early kidney development. Cell 74: 679-691.

Liang, Y., T.L. Jetton, E.C. Zimmerman, H. Najafi, F.M. Matschinsky, and M.A. Magnuson. 1991. Effects of alternate RNA splicing on glucokinase isoform activities in the pancreatic islet, liver, and pituitary. J. Biol. Chem. 266: 69997007.

Mahone, M., E.E. Saffman, and P. Lasko. 1995. Localized Bicaudal- $C$ RNA encodes a protein containing a $\mathrm{KH}$-domain, the RNA-binding motif of FMR-1. EMBO $\%$. (in press).

Mello C.C., J.M. Kramer, D. Stinchcomb, and V. Ambros. 1991. Efficient gene transfer in C. elegans: Extrachromosomal maintenance and integration of transforming sequences. EMBO I. 10: 3959-3970.

Meyer, B.J. and L.P. Casson. 1986. Caenorhabditis elegans compensates for the difference in $\mathrm{X}$ chromosome dosage between the sexes by regulating transcript levels. Cell 47: 871-881.

Richard, S., D. Yu, K. Blumer, D. Hausladen, M.W. Olszowy, P.A. Connelly, and A.S. Shaw. 1995. Association of p62, a multifunctional $\mathrm{SH} 2$ - and SH3-domain-binding protein, with src family tyrosine kinases, grb2 and phospholipase $\mathrm{C}_{\gamma}$ 1. Mol. Cell. Biol. 15: 186-197.

Ruvolo, V., J.E. Hill, and A. Levitt. 1992. The Tc2 transposon of Caenorhabditis elegans has the structure of a self-regulated element. DNA Cell Biol. 11: 111-122.

Sagata, N., M. Oskarsson, T. Copeland, I. Brumbaugh, and G.F. Vande Woude. 1988. Function of c-mos proto-oncogene product in meiotic maturation in Xenopus oocytes. Nature 335: 519-525.

Siomi, H., M.J. Matunis, W.M. Michael, and G. Dreyfuss. 1993a. The pre-mRNA binding $\mathrm{K}$ protein contains a novel evolutionarily conserved motif. Nucleic Acids Res. 21: 11931198.

Siomi, H., M.C. Siomi, R.L. Nussbaum, and G. Dreyfuss. 1993b. The protein product of the fragile X gene FMR1, has characteristics of an RNA-binding protein. Cell 74: 291-298.

Takimoto, M., T. Tomonaga, M. Matunis, M. Avigan, H. Krutzsch, G. Dreyfuss, and D. Levens. 1993. Specific binding of heterogeneous ribonucleoprotein particle protein $\mathrm{K}$ to the human c-myc promoter, in vitro. I. Biol. Chem. 268: 1824918258.

Taylor, S.J. and D. Shalloway. 1994. An RNA-binding protein associated with Src through its $\mathrm{SH} 2$ and $\mathrm{SH} 3$ domains in mitosis. Nature 368: 867-871.

Toda, T., A. Iida, T. Miwa, Y. Nakamura, and T. Imai. 1994. Isolation and characterization of a novel gene encoding nuclear protein at a locus (D11S636) tightly linked to multiple endocrine neoplasia type 1 (MEN1). Hum. Mol. Genet. 3: $465-470$.

Verkerk, A.J.M.H., M. Pieretti, J.S. Sutcliffe, Y.-H. Fu, D.P.A. Kuhl, A. Pizzuti, O. Reiner, S. Richards, M.F. Victoria, F. Zhang, et al. 1991. Identification of a gene (FMR-1) containing a CGG repeat coincident with a breakpoint cluster region exhibiting length variation in fragile $\mathrm{X}$ syndrome. Cell 65: 905-914.

Wang, L.L., S. Richard, and A.S. Shaw. 1995. p62 association with RNA is regulated by tyrosine phosphorylation. J. Biol. Chem. 270: 2010-2013.

Weng, Z., S.M. Thomas, R.J. Rickles, J.A. Taylor, A.W. Brauer, C. Seidel-Dugan W.M. Michael, G. Dreyfuss, and J.S. Brugge. 1994. Identification of Src, Fyn, and Lyn SH3-binding proteins: Implications for a function of SH3 domains. Mol. Cell. Biol. 14: 4509-4521.

Williams, B.D., B. Schrank, C. Huynh, R. Shownkeen, and R.H Waterston. 1992. A genetic mapping system in Caenorhab ditis elegans based on polymorphic sequence-tagged sites. Genetics 131: 609-624.

Wilson, R., R. Ainscough, K. Anderson, C. Baynes, M. Berks, J Bonfield, J. Burton, M. Connell, T. Copsey, J. Cooper, et al. 1994. 2.2 Mb of contiguous nucleotide sequence from chromosome III of C. elegans. Nature 368: 32-38.

Wong, G., O. Müller, R. Clar, L. Conroy, M. Moran, P. Polakis, and F. McCormick. 1992. Molecular cloning and nucleic acid binding properties of the GAP-associated tyrosine phosphoprotein p62. Cell 69: 551-558.

Yew, N., M. Strobel, and G.F. Vande Woude. 1993. Mos and the cell cycle: The molecular basis of the transformed phenotype. Curr. Opin. Genet. Dev. 3: 19-25.

Yochem, J. and I. Greenwald. 1993. A gene for a low density lipoprotein receptor-related protein in the nematode Cae norhabditis elegans. Proc. Nat1. Acad. Sci. 90: 4572-4576. 


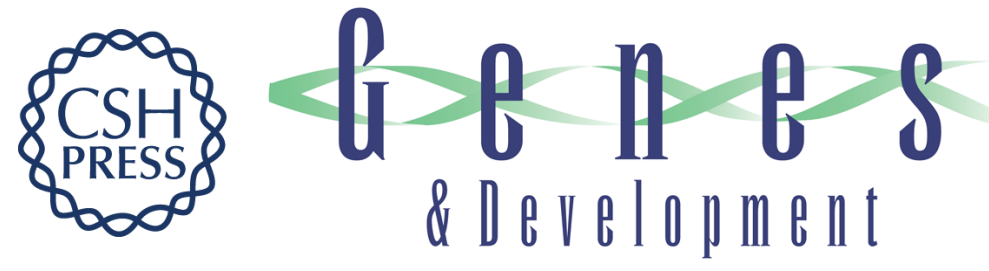

\section{Mutations in gld-1, a female germ cell-specific tumor suppressor gene in Caenorhabditis elegans, affect a conserved domain also found in Src-associated protein Sam68.}

A R Jones and T Schedl

Genes Dev. 1995, 9:

Access the most recent version at doi:10.1101/gad.9.12.1491

References This article cites 54 articles, 22 of which can be accessed free at:

http://genesdev.cshlp.org/content/9/12/1491.full.html\#ref-list-1

License

Email Alerting Service

Receive free email alerts when new articles cite this article - sign up in the box at the top right corner of the article or click here.

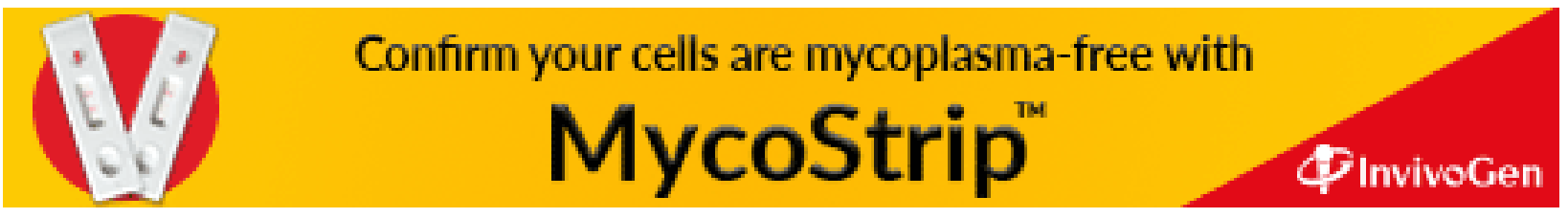

